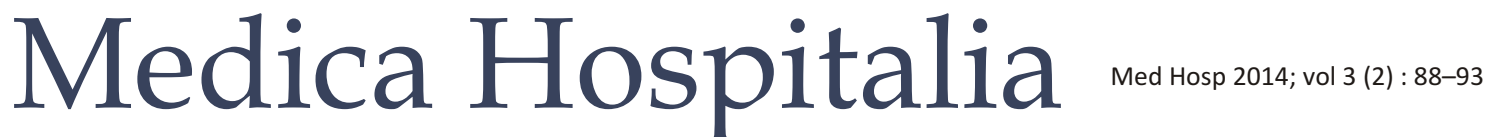

Original Article

\section{Faktor Risiko Kurang Pendengaran Sensorineural Pada Penderita Penyakit Jantung Koroner}

\author{
Muyassaroh, Ika Windi \\ Departemen IK THT-KL Fakultas Kedokteran Universitas Diponegoro / RSUP Dr. Kariadi Semarang
}

\begin{abstract}
Abstrak
Latar belakang : Kurang pendengaran sensorineural (KPSN) dapat terjadi pada penderita jantung koroner yang mendapat pengobatan aspirin atau yang disertai dengan penyakit penyerta hipertensi, diabetes melitus atau hiperlipidemia. penyakit kardiovaskuler dan gangguan arteri perifer berhubungan dengan gambaran audiogram berupa penurunan ambang dengar pada frekuensi rendah

Metode : Design penelitian belah lintang. Penelitian di unit jantung RSUP Dr. Kariadi Semarang. Pengambilan sampel dengan cara consecutive sampling. Sampel yang telah ditentukan sebanyak 78. Semua sampel dilakukan pemeriksaan audiometri nada murni dengan hasil KPSN. Penggunaan aspirin dosis rendah, riwayat hipertensi, DM, hiperkolesterol, hiperlipidemi didapatkan dari kuesener dan Rekam medik. Dilakukan pemeriksaan tekanan darah, pemeriksaan laboratorium darah. Analisis data dengan uji Chi square dan regresi logistik. Protokol penelitian telah disetujui oleh Komisi Etik Penelitian Kedokteran FK UNDIP / RSUP Dr. Kariadi Semarang.

Hasil : Didapatkan 78 subyek terdiri dari 47 (60,3\%) laki-laki dan $31(39,7 \%)$ perempuan. Sebagian besar subjek penelitian $(70,6 \%)$ berusia 51-60 tahun. Kejadian KPSN pada penyakit jantung koroner sebanyak 46 (59\%). Hipertensi $(p=0,743, \mathrm{RP}=1,167$, $95 \% \mathrm{Cl}=0,463-2,944)$, DM $(p=0,219, \mathrm{RP}=1,905$, $95 \% \mathrm{Cl}=0,677-5,36)$, Hiperlipidemi $(p=0,414, \mathrm{RP}=1,462,95 \%$ $\mathrm{Cl}=0,587-3,638)$ tidak bermakna terhadap kejadian KPSN. Didapatkan perbedaan bermakna pada penggunaan aspirin dosis rendah $(p=0,023, \mathrm{RP}=0,3,95 \% \mathrm{Cl}=0,104-0,868)$.

Simpulan : Hipertensi, DM, Hiperlipidemi bukan merupakan faktor risiko KPSN. Penggunaan aspirin dosis rendah merupakan faktor protektif terhadap KPSN.
\end{abstract}

Kata kunci : Penyakit jantung koroner, Faktor risiko, Kurang pendengaran sensorineural

\section{Risk Factors on Sensorineural Hearing Lost Coronary Heart Disease Patients}

\begin{abstract}
Background : Sensori-Neural Hearing Loss (SNHL) may occur in patients with coronary heart disease who were prescribed aspirin or accompanied by co-morbidities include hypertension, diabetes mellitus or hyperlipidemia . Cardiovascular disease and peripheral arterial disorders are known to be associated with the decrease of hearing threshold at low frequencies in the audiogram

Methods : Cross-sectional designed study were done at Heart and Cardiovascular Unit Dr. Kariadi Hospital. 78 samples were taken by consecutive sampling. Each sample underwent blood pressure, blood laboratory, and pure tone audiometric examination with SNHL results. The use of low-dose aspirin, history of hypertension, diabetes, hypercholesterolemia, hyperlipidemia obtained from questionnaires and medical records. The data were analyzed with Chi square test and logistic regression. The study protocol has been approved by the Research Ethics Committee of Medical Faculty of Diponegoro University / Dr. Kariadi Hospital .

Results: There were 78 subjects consisted of $47(60.3 \%)$ males and $31(39.7 \%)$ women. Most of the study subjects (70.6\%) aged 51-60 years. Sensorineural hearing lost incidence of coronary heart disease were 46 (59\%). Hypertension ( $p=0.743, \mathrm{RP}=1.167,95 \%$ $\mathrm{Cl}=0.463-2.944)$, diabetes $(p=0.219, \mathrm{RP}=1.905,95 \%$ $\mathrm{Cl}=0.677-5.36)$, and Hyperlipidemia $(p=0.414, \mathrm{RP}=1.462,95 \%$ $\mathrm{Cl}=0.587-3.638)$ was not significant on the SNHL incidence. Significant differences were obtained in the use of low-dose aspirin ( $p=0.023, \mathrm{RP}=0,395 \% \mathrm{Cl}=0.104-0.868)$.

Conclusion : Hypertension, diabetes, and hyperlipidemia are not a risk factor of SNHL. The use of low-dose aspirin is a protector of SNHL
\end{abstract}

Keywords : coronary heart disease, risk factors, sensory neural hearing loss 


\section{PENDAHULUAN}

Kurang pendengaran sensorineural (KPSN) adalah penurunan ketajaman pendengaran yang disebabkan oleh lesi pada koklea dan/atau nervus koklearis, dapat unilateral atau bilateral, bersifat permanen atau reversible. ${ }^{1}$ KPSN dapat terjadi pada penderita jantung koroner yang mendapat pengobatan aspirin atau yang disertai dengan penyakit penyerta hipertensi, diabetes melitus atau hiperlipidemia. ${ }^{2}$

Penyakit jantung koroner (PJK) disebabkan karena penyempitan arteri koronaria akibat proses aterosklerosis atau spasme atau keduanya. Obat yang digunakan antara lain obat anti trombotik (aspirin dosis rendah, antagonis reseptor ADP (thienopyridin) contoh : clopidogrel dan ticlopidine); obat penurun kolesterol (statin); ACE-inhibitor; beta blocker; dan calcium channel blocker. Uji klinis mengenai dosis optimal aspirin untuk pencegahan trombosis pada penderita penyakit kardiovaskuler adalah sebesar 75 hingga $80 \mathrm{mg}$ per hari. ${ }^{3,4}$ Salisilat merupakan komponen aktif dari aspirin, yang merupakan salah satu jenis obat yang digunakan secara luas sebagai analgetika, anti piretik, anti inflamasi dan anti trombosis untuk pencegahan penyakit jantung koroner. ${ }^{4,5}$ KPSN akibat konsumsi salisilat berhubungan dengan konsentrasi dalam darah. Kadar puncak salisilat pada plasma darah setelah 7 hari penggunaan aspirin per oral dengan dosis $300-1000 \mathrm{mg}$ pada dewasa sehat berkisar antara 3-10 mg/dL. Pada kadar total salisilat darah rata-rata $11 \mathrm{mg} / \mathrm{dL}$ terdapat penurunan ambang dengar sebesar $12 \mathrm{~dB} .{ }^{6}$ Aspirin mempengaruhi fungsi elektrofisiologis dan histologis sel rambut luar sehingga terjadi gangguan pendengaran. ${ }^{7}$ Wei et al (2010) melaporkan pemberian aspirin dosis tinggi bersifat neurotoksik terhadap syaraf ganglion spiralis dan menyebabkan penurunan aksi potensial nervus koklearis yang persisten dan signifikan. ${ }^{8}$ Friedland (2009) melaporkan penyakit kardiovaskuler dan gangguan arteri perifer berhubungan dengan gambaran audiogram berupa penurunan ambang dengar pada frekuensi rendah dan dapat digunakan sebagai skrining adanya penyakit kardiovaskuler. ${ }^{2}$

Hipertensi, diabetes melitus dan hiperlipidemia secara langsung dapat mempengaruhi aliran pembuluh darah koklea dan menurunkan transportasi nutrisi akibat perubahan pembuluh darah dan secara tidak langsung menurunkan aliran pembuluh darah yang berakibat degenerasi sekunder pada saraf kranial kedelapan. ${ }^{9}$ Marchiori (2006) melaporkan dari 72 subjek yang menderita hipertensi 46,8\% mengalami KPSN dan dinyatakan hipertensi merupakan faktor risiko independen terhadap kejadian KPSN. ${ }^{10}$ Penelitian Bainbridge (2011) melaporkan bahwa terdapat hubungan signifikan antara kurang pendengaran pada frekuensi rendah dan frekuensi tinggi dengan kadar HDL rendah dan penyakit jantung koroner pada penderita
DM. ${ }^{11}$ Dinis (2009) melaporkan dari 50 orang penderita diabetes melitus berusia lebih dari 45 tahun, 30 orang $(60 \%)$ mengalami KPSN. ${ }^{9}$ Sedangkan Swaminathan (2011) melakukan evaluasi audiometri pada penderita hiperlipidemia, didapatkan $40 \%$ mengalami KPSN. ${ }^{12}$ Tujuan penelitian ini adalah mengetahui apakah penggunaan aspirin dosis rendah, hipertensi, diabetes melitus dan hiperlipidemia merupakan faktor risiko KPSN pada penderita jantung koroner.

\section{METODE}

Disain penelitian belah lintang. Penelitian dilakukan di unit jantung RSUP Dr. Kariadi Semarang pada bulan Nopember dan Desember 2014. Sampel penderita penyakit jantung koroner umur 20-60. Hasil otoskopi telinga dalam batas normal, hasil timpanometri tipe A. Penderita gangguan fungsi ginjal atau gagal ginjal atau menjalani hemodialisis, Riwayat kurang pendengaran sejak kecil, Riwayat kemoterapi, Riwayat trauma kepala dan atau telinga, Riwayat terpapar bising, Riwayat kurang pendengaran dalam keluarga di eksklusikan. Pengambuilan sampel dengan cara consecutive sampling. Sampel yang telah ditentukan sebanyak 78 . Semua sampel dilakukan pemeriksaan audiometri nada murni dengan hasil KPSN. Penggunaan aspirin dosis rendah, riwayat hipertensi, riwayat DM, riwayat hiperkolesterol, riwayat hiperlipidemi didapatkan dari kuesener dan Rekam medik. Dilakukan pemeriksaan tekanan darah, pemeriksaan laboratorium gula darah dan kadar lemak total. Analisis data dengan menggunakan uji Chi square untuk menilai faktor risiko KPSN. Besar risiko (Rasio Prevalens/RP) dengan interval kepercayaan CI 95\%, dan $a=5 \%$. Uji multivariat dengan regresi logistik untuk

\begin{tabular}{|c|c|c|}
\hline Variabel & & Total $n=78$ \\
\hline \multirow[t]{2}{*}{ Hipertensi (\%) } & $(+)$ & $48(61,5)$ \\
\hline & $(-)$ & $30(38,5)$ \\
\hline \multirow[t]{2}{*}{ Diabetes melitus (\%) } & $(+)$ & $23(29,5)$ \\
\hline & $(-)$ & $55(70,5)$ \\
\hline \multirow[t]{2}{*}{ Hiperlipidemia (\%) } & $(+)$ & $36(46,2)$ \\
\hline & $(-)$ & $42(53,8)$ \\
\hline \multirow[t]{2}{*}{ Aspilet (\%) } & $(+)$ & $52(66,7)$ \\
\hline & $(-)$ & $26(33,3)$ \\
\hline \multirow[t]{2}{*}{ KPSN (\%) } & $(+)$ & $46(59)$ \\
\hline & $(-)$ & $32(41)$ \\
\hline \multirow[t]{2}{*}{ Derajat KPSN (\%) } & ringan & $35(75)$ \\
\hline & sedang & $11(25)$ \\
\hline
\end{tabular}


mencari faktor risiko yang paling berpengaruh terhadap kejadian KPSN. Faktor yang dinilai berpengaruh bila variabel tersebut pada uji multivariat dengan $p<0,25$. Protokol penelitian telah disetujui oleh Komisi Etik Penelitian Kedokteran FK UNDIP/RSUP Dr. Kariadi Semarang.

\section{HASIL}

Didapatkan 78 subyek penelitian terdiri dari $47(60,3 \%)$ laki-laki dan 31 (39,7\%) perempuan. Median umur subyek 54 tahun dengan umur terendah 25 tahun dan tertinggi 60 tahun. Sebagian besar subjek penelitian $(70,6 \%)$ berusia $51-60$ tahun.

Hipertensi $(p=0,743), \mathrm{DM}(p=0,219)$, Hiperlipidemi $(p=0,414)$ bukan merupakan faktor risiko KPSN. Penggunaan aspirin dosis rendah berpengaruh $(p=0,023)$ sebagai proteksi terhadap KPSN pada penderita jantung koroner.

Pada penderita jantung koroner yang menggunakan aspirin dosis rendah merupakan faktor protektif terhadap KPSN.

\section{PEMBAHASAN}

Penelitian ini bertujuan untuk mengetahui faktor risiko KPSN pada penderita jantung koroner. Penelitian dilakukan pada 78 penderita jantung koroner dengan jumlah subyek laki-laki. Sebagian besar subyek berusia $51-60$ tahun dengan rerata umur 54 tahun dengan umur terendah 25 tahun dan tertinggi 60 tahun. Empat puluh enam (59\%) mengalami KPSN. Sebagian besar KPSN derajat ringan. Subyek yang menderita hipertensi lebih banyak daripada yang tidak mengalami hipertensi yaitu sebesar $61,5 \%$ dari total subyek penelitian. Hipertensi merupakan salah satu faktor risiko utama penyakit jantung koroner. Penelitian sebelumnya dikatakan terdapat hubungan yang signifikan antara hipertensi dengan KPSN. ${ }^{13}$ Tachibana et al melaporkan lokasi lesi primer akibat hipertensi terdapat pada stria vaskularis dan organon korti. ${ }^{14}$ Stria vaskularis kaya dengan kapiler dan mendasari terjadinya endocochlear potential untuk perambatan sinyal auditori ke sistem syaraf pusat. Arteri yang menyuplai stria vaskularis tidak memiliki anastomosis untuk memberikan suplemen aliran darah pada keadaan spasme dan atau oklusi. ${ }^{14}$ Dari hasil uji Chi square pada penelitian ini menunjukkan hipertensi tidak

TABBEL 2

Faktor risiko hipertensi, DM, hiperlipidemi, penggunaan aspirin dosis rendah pada KPSN

\begin{tabular}{lccccc} 
Variabel & KPSN (+)\% & KPSN (-)\% & $\boldsymbol{p}$ & RP & 95\% CI \\
\hline Hipertensi (+) & $29(37,2)$ & $19(24,4)$ & 0,743 & 1,167 & $0,463-2,944$ \\
Hipertensi (-) & $17(21,8)$ & $13(16,7)$ & & & \\
DM (+) & $16(20,5)$ & $7(9)$ & 0,219 & 1,905 & $0,677-5,36$ \\
DM (-) & $30(38,5)$ & $25(32,1)$ & & & \\
Hiperlipidemi (+) & $23(29,5)$ & $13(16,7)$ & 0,414 & 1,462 & $0,587-3,638$ \\
Hiperlipidemi (-) & $23(29,5)$ & $19(24,4)$ & & & \\
Aspirin (+) & $26(33,3)$ & $26(33,3)$ & 0,023 & 0,300 & $0,104-0,868$ \\
Aspirin (-) & $20(25,6)$ & $6(7,7)$ & & & \\
\hline
\end{tabular}

TABEE 3

Analisis regresi logistik multivariat factor risiko KPSN

\begin{tabular}{clcccc} 
Step & Variabel & B & $\boldsymbol{p}$ & RP & $\mathbf{9 5 \%}$ CI \\
\hline 1 & DM & 0,821 & 0,137 & 2,272 & $0,771-6,693$ \\
& Aspilet & $-1,312$ & 0,018 & 0,269 & $0,091-0,799$ \\
& Konstan & $-0,065$ & 0,954 & 0,937 & \\
\multirow{2}{*}{2} & Aspilet & $-1,204$ & 0,026 & 0,300 & $0,104-0,868$ \\
& Konstan & 1,204 & 0,096 & 3,333 & \\
& & & &
\end{tabular}


berhubungan dengan kejadian KPSN dengan nilai $p=0,743, \mathrm{RP}=1,167 \quad(95 \% \mathrm{CI}=0,463-2,944)$. Hal ini berlawanan dengan penelitian sebelumnya oleh Esparza et al. pada pasien berusia 29-64 tahun dimana pasien dengan hipertensi mengalami vertigo lebih sering dan menunjukkan audiogram yang menurun (descending), OAE abnormal, dan retinopati dibandingkan pasien tanpa hipertensi. ${ }^{15}$ De Moraes Marchiori et al menunjukkan hipertensi sebagai faktor yang mempercepat degenerasi sistem auditori setelah meneliti hubungan yang signifikan antara kurang pendengaran dan hipertensi. ${ }^{10}$ Pada penelitian ini kemungkinan tidak terdapat hubungan yang signifikan dikarenakan dari subyek yang menderita hipertensi sebagian besar telah mendapat terapi anti hipertensi rutin sehingga tekanan darah yang terkendali dapat mencegah terjadinya KPSN. Penderita DM pada penelitian ini didapatkan lebih sedikit daripada yang tidak mengalami DM. Sebanyak 16 orang $(20,5 \%)$ subyek dengan DM mengalami KPSN. Dari hasil uji Chi square menunjukkan DM tidak berhubungan dengan kejadian KPSN dengan nilai $\mathrm{p}=0,219, \mathrm{RP}=1,905 \quad(95 \% \mathrm{CI}=0,677-5,36)$. Hal ini bertentangan dengan penelitian sebelumnya yang menyatakan terdapat hubungan yang signifikan antara DM dan KPSN. Penelitian Diniz (2009) pada penderita DM dibandingkan dengan kontrol non DM terdapat perbedaan ambang dengar yang signifikan antara keduanya dimana terdapat penurunan ambang pendengaran pada penderita DM. ${ }^{16}$ Penelitian lain oleh Swaminathan (2011) terdapat perbedaan ambang dengar yang signifikan antara kelompok DM dibandingkan kontrol sehat berusia sama 40-50 tahun dimana kelompok DM memiliki ambang dengar yang lebih rendah. ${ }^{12}$ Perbedaan hasil penelitian ini dibandingkan penelitian sebelumnya yaitu pada penelitian ini dilakukan pada penderita jantung koroner dan tidak dibandingkan dengan kontrol yang sehat. Sebagian besar subyek yang menderita DM pada penderita jantung koroner juga telah mendapatkan terapi rutin DM dan kontrol rutin. Selain itu dari total subyek penelitian yang menderita DM hanya sebesar 29,5\% dibandingkan yang tidak menderita DM sebesar 71,5\% sehingga tidak terdapat hubungan yang signifikan.

Hubungan antara DM dengan KPSN masih banyak terdapat perbedaan. Dasil penelitian sebagian menyatakan terdapat hubungan yang signifikan sebagian lain tidak. Efek dari perbedaan variabel seperti durasi diabetes, kontrol kadar gula darah, dan adanya kerusakan organ pada penurunan pendengaran belum diklarifikasi. ${ }^{17}$

Subyek yang menderita hiperlipidemia dari total subyek penelitian sebesar $46,2 \%$ dan dari subyek yang menderita hiperlipidemia didapatkan 23 orang (29,5\%) mengalami KPSN. Dari hasil uji Chi square menunjukkan hiperlipidemia tidak berhubungan dengan kejadian KPSN dengan nilai $p=0,414, \mathrm{RP}=1,462 \quad(95 \% \mathrm{CI}=0,587$ -
3,638). Hasil penelitian ini bertentangan pula dengan penelitian sebelumnya oleh Swaminathan (2011) dimana terdapat perbedaan yang signifikan antara ambang dengar kelompok yang menderita hiperlipidemia dibandingkan kontrol sehat. Selain itu penelitian oleh Evans et al (2006) menyatakan hiperlipidemia kronik berhubungan dengan peningkatan kadar trigliserida dapat menurunkan ambang dengar namun konsumsi diet tinggi lemak dalam jangka pendek meskipun terjadi hiperlipidemia tapi tidak menurunkan ambang dengar yang signifikan bila dibandingkan dengan kontrol sehat. Pada penelitian tersebut subyek tidak mendapatkan terapi hiperlipidemia. ${ }^{18}$ Perbedaan hasil penelitian ini dengan penelitian sebelumnya selain subyek penelitian yang diambil seluruhnya merupakan penderita jantung koroner juga pada subyek penelitian yang menderita hiperlipidemia telah diberikan terapi hiperlipidemia dan kontrol rutin sehingga tidak terdapat hubungan yang signifikan antara KPSN pada penderita jantung koroner dengan hiperlipidemia dibandingkan penderita jantung koroner yang tidak menderita hiperlipidemia.

Pada penelitian ini sebanyak 52 (66,7\%) subyek menggunakan aspirin dosis rendah. Subyek yang mengkonsumsi aspirin dosis rendah yang mengalami KPSN sebanyak 26 orang (33,3\%) sedangkan yang tidak mengalami KPSN juga 26 orang (33,3\%). Pada penderita jantung koroner yang menggunakan aspirin dosis rendah merupakan faktor protektif terhadap KPSN. Bertentangan dengan penelitian sebelumnya oleh Kakehata (1996) dan Almeida dkk (2011) yaitu didapatkan pemberian aspirin mempengaruhi fungsi elektrofisiologis dan histologis sel rambut luar sehingga terjadi gangguan pendengaran. Sel rambut luar yang diberikan larutan mengandung salisilat menunjukkan vesikulasi sisterna pada dinding lateral sel rambut luar, penurunan turgiditas dan elektromotilitas. ${ }^{19,20}$ Chen et al (2009) dan Wei et al (2010) melaporkan pemberian aspirin dosis tinggi bersifat neurotoksik terhadap syaraf ganglion spiralis dan menyebabkan penurunan aksi potensial nervus koklearis yang persisten dan signifikan. ${ }^{10,15,21}$ Penelitian tersebut sebelumnya di atas dilakukan pada binatang tikus dengan pemberian aspirin dosis tinggi yaitu $200 \mathrm{mg} / \mathrm{kgBB} /$ hari selama 5 hari dalam seminggu dan diberikan selama 3 minggu. Namun meskipun terjadi penurunan jumlah sel ganglion spiralis dan penurunan aksi potensial nervus koklearis, penelitian pada tikus tersebut didapatkan penguatan ekspresi motor protein prestin pada sel rambut luar sehingga memperkuat elektromotilitas sel rambut luar dan memperkuat hasil pengukuran DPOAE. ${ }^{22}$ meskipun terjadi penurunan amplitudo cochlear compound action potential (CAP) dan auditory brainstem response (ABR). ${ }^{23,24}$ Salisilat menyebabkan hilangnya elektromotilitas sel rambut luar setelah pemberian dosis tinggi yang bersifat akut dan akan kembali normal setelah penghentian obat, sehingga menyebabkan kurang pendengaran dan tinitus 
yang bersifat reversibel. ${ }^{25,26,27}$

Siklooksigenase dan lipoksigenase, enzim penting yang terlibat pada metabolisme asam arakidonat, merupakan target utama obat NSAID termasuk aspirin. Kaskade asam arakidonat dan metabolit yang dihasilkan terlibat dalam mempertahankan fungsi telinga dalam. Penggunaan aspirin dosis tinggi dapat menimbulkan tinitus pada penelitian pada manusia dan gangguan fungsi sel rambut luar pada percobaan hewan. ${ }^{28}$ Pada penelitian lain dilaporkan aspirin memiliki efek protektif terhadap berbagai kelainan telinga dalam. Salisilat dilaporkan mengurangi ototoksisitas gentamisin dan melindungi fungsi pendengaran serta fungsi ginjal pada penggunaan sisplatin. ${ }^{29,30}$ Pada penelitian ini didapatkan aspirin dosis rendah merupakan faktor protektif terhadap KPSN pada penderita jantung koroner. Aspirin merupakan NSAID yang memiliki efek anti inflamasi maupun anti oksidan. Aspirin menghambat produksi berlebihan dari metabolit radang seperti prostaglandin, tromboksan dan leukotrien yang dapat mengganggu fungsi telinga dalam. ${ }^{31}$ Sebagai anti oksidan aspirin dapat mengurangi produksi ROS (reactive oxygen species) akibat proses iskemia telinga dalam yang terjadi pada gangguan kardiovaskuler penderita jantung koroner. ${ }^{28}$

\section{Keterbatasan Penelitian}

Penelitian ini tidak dilakukan pemeriksaan kadar salisilat darah sehingga tidak diketahui kadar salisilat darah setelah penggunaan aspirin dosis rendah dan hubungannya dengan kejadian KPSN pada penderita jantung koroner. Faktor risiko diabetes melitus dan hiperlipidemia didapatkan dari rekam medis dan kuesioner tanpa dilakukan pemeriksaan laboratorium darah yang lebih objektif sehingga ada recall bias.

\section{SIMPULAN}

Hipertensi, DM, Hiperlipidemi bukan merupakan factor risiko KPSN pada penderita jantung koroner. Penggunaan aspirin dosis rendah merupakan faktor protektif terhadap kejadian KPSN pada penderita jantung koroner. Perlu penelitian lebih lanjut mengenai KPSN pada penderita jantung koroner dengan mengukur kadar salisilat darah, kadar gula darah dan kadar lipid dalam darah.

\section{DAFTAR PUSTAKA}

1. Soetirto I, Hendarmin H, Bashiruddin J. Gangguan pendengaran (tuli). In: Soepardi E, Iskandar N, Bashiruddin J, Restuti R, editors. Buku Ajar Ilmu Kesehatan Telinga, Hidung, Tenggorok, Kepala dan Leher. 6 ed. Jakarta: Balai Penerbit FKUI; 2007.p. 10-22.

2. Friedland DR, Cederberg C, Tarima S. Audiometric pattern as a predictor of cardiovascular status: development of a model for assessment of risk. The Laryngoscope. 2009;119:473-86.
3. Campbell CL, Smyth S, Montalescot G, Steinhubl SR. Aspirin Dose for the Prevention of Cardiovascular Disease A Systematic Review.JAMA. 2007;297:2018-24.

4. Pearson TA, Blair SN, Daniels SR, Eckel RH, Fair JM, Fortmann SP, et al. AHA Guidelines for Primary Prevention of Cardiovascular Disease and Stroke: 2002 Update Consensus Panel Guide to Comprehensive Risk Reduction for Adult Patients Without Coronary or Other Atherosclerotic Vascular Diseases. Circulation. 2002;106:388-91.

5. Cheng T. The history of aspirin. Tex Heart Inst J 2007;34:392-3.

6. Day R, Graham G, Bieri D, Brown M, Cairns D, Harris G, et al. Concentration-response relationships for salicylate-induced ototoxicity in normal volunteers. Br J clin Pharmac 1989;28:695702.

7. Almeida-Silva ID, Oliveira JD, Rossato M, Salata FF, Hyppolito M. Spontaneous reversibility of damage to outer hair cells after sodium salicylate induced ototoxicity. The Journal of Laryngology \& Otology. 2011;125:786-94.

8. Wei L, Ding D, Salvi R. Salicylate-induced degeneration of cochlea spiral ganglion neurons-apoptosis signaling. Neuroscience. 2010;168(1):288-99.

9. Sherwood L. Fisiologi Manusia dari sel ke system. edisi ke-2. Jakarta: Penerbit Buku Kedokteran EGC, 1996.

10. Marchiori LLdM, Filho EdAR, Matsuo T. Hypertension as a factor associated with hearing loss. Rev Bras Otorrinolaringol 2006;72(4):533-40. 2006;72(4):533-40.

11. Bainbridge KE, Hoffman HJ, Cowie CC. Risk factors for hearing impairment among U.S. adults with diabetes. National health and nutrition examination survey 19992004. Diabetes Care. 2011;34:1540-5.

12. Swaminathan A, Sambandam R, Bhaskaran M. Evaluation of the auditory effects of hyperlipidaemia and diabetes mellitus by using audiometry. Journal of Clinical and Diagnostic Research. 2011;5(8):1528-32.

13. Doroszewska G, Kazmierczak H, Doroszewski W. Risk factor for inner ear diseases. Pol Merkur Lekarski. 2000;9:751-4.

14. Rozanska-Kudelska M. Hearing loss in patients with diabetes mellitus type I. Otolaryngol Pol. 2002;5:607-10.

15. Esparza D, Jauregui-Renaud K, Morelo C, Muhl G, Mendez M, Carillo N. Systemic high blood pressure and inner ear dysfunction a preliminary study. Clin Otoalyngol. 2007;32:173-8.

16. Diniz T, Guida H. Hearing loss in patients with diabetes mellitus. Braz J Otorhinolaryngol. 2009;75(4):573-8.

17. Maia C, Campos Cd. Diabetes mellitus as etiological factor of hearing loss. Rev Bras Otorrinolaringol. 2005;71:208-14.

18. Evans MB, Tonini R, Shope CD, Oghalai JS, Jerger JF, Insull W, et al. Dyslipidemia and auditory function. Otol Neurotol. 2006;27(5):609-14.

19. Kakehata S, Santos-Sacchi J. Effects of Salicylate and Lanthanides on Outer Hair Cell Motility and Associated Gating Charge. The Journal of Neuroscience. 1996;16(16):4881-9.

20. Almeida-Silva ID, Oliveira JD, Rossato M, Salata FF, Hyppolito M. Spontaneous reversibility of damage to outer hair cells after sodium salicylate induce ototoxicity. The Journal of Laringology \& Otology.2011;125:786-94.

21. Feng H, Yin S-H, Tang A-Z, Tan S-H. Salicylate initiates apoptosis in the spiral ganglion neuron of guinea pig cochlea by activating caspase-3. Neurochem Res. 2011;36:1108-15.

22. Chen G-D, Li M, Tanaka C, Bielefeld E, Kermany M, Salvi R, et al. Effect of chronic salicylate treatment on age-related cochlear degeneration. Abstr Assoc Res Otolarygol. 2009;32:197.

23. Yang K, Huang Z, Liu Z, Xiao B, Peng J. Long-term administration of salicylate enhances prestin expression in rat cochlea. Int J Audiol. 2009;48:18-23.

24. Chen G-D, Kermany MH,D'Elia A, Ralli M, Tanaka C, Biefeld 
EC, at al. Too Much of a good thing: longterm treatment with salicylate strengthens outer hair cell function but impairs auditory neural activity. Hearing Research.2010;265:63-9

25. Cazals Y. Auditory sensori-neural alterations induced by salicylate. Progress in Neurobiology. 2000;62:583-631.

26. Chyka PA, Erdman A, Christianson G, Wax PM, Booze LL, Manoguerra AS, et al. Salicylate poisoning: An evidence-based consensus guideline for out-of-hospital management. Clinical toxicology. [Practice guideline]. 2007;45:95-131.

27. Schuman R. Ototoxicity. In: Bailey B, editor. Head and neck surgery-Otolaryngology. 4th ed. Philadelphia: Lipincott Williams \& Wilkins: 2006.p.645-9

28. Hoshino T, Tabuchi K, Hara A. Effects of NSAIDs on the inner ear: possible involvement in cochlear protection. Pharmaceuticals. 2010;3:1286-95.
29. Sha S, Schacht J. Salicylate attenuates gentamicin-induced ototoxicity. Lab Invest. 1999;79:807-13.

30. Li G, Sha S, Zotova E, Arezzo J, Water TVd, Schacht J. Salicylate protects hearing and kidney function from cisplatin toxicity without compromising its oncolytic action. Lab Invest. 2002;82:585-96.

31. Tabuchi K, Ito Z, Tsuji S, Wada T, Takahashi K, Hara A, et al. The contribution of phospholipase A2 to the cochlear dysfunction induced by transient ischemia. Hear Res. 2000;144:1-7. 